\title{
Soluble Fc $\gamma$ receptor III (CD16) and eicosanoid concentrations in gut lavage fluid from patients with inflammatory bowel disease: reflection of mucosal inflammation
}

D W Hommes, J Meenan, $M$ de Haas, F J W ten Kate, A E G Kr von dem Borne, G N J Tytgat, S J H van Deventer
Centre for

Haemostasis,

Thrombosis,

Atherosclerosis and

Inflammation

Research

D W Hommes

$\mathrm{S} J \mathrm{H}$ van Deventer

Department of

Gastroenterology

D W Hommes

J Meenan

G N J Tytgat

$S \mathrm{~J} H$ van Deventer

Department of

Pathology

F J W ten Kate

Department of

Haematology

A E G Kr von dem Borne

Academic Medical Centre, University of Amsterdam, the

Netherlands

Central Laboratory of the Netherlands Red Cross Blood

Transfusion Service and Laboratory for

Experimental and

Clinical Immunology,

Amsterdam, the

Netherlands

$M$ de Haas

Correspondence to:

Dr D W Hommes,

Department of

Gastroenterology and

Hepatology, Academic

Medical Centre,

Meibergdreef 9, $1005 \mathrm{AZ}$

Amsterdam, the

Netherlands.

Accepted for publication

23 October 1995

\begin{abstract}
Background-Activated neutrophils cause tissue injury in inflammatory bowel disease (IBD). Upon activation, they shed soluble Fc gamma IIIb receptors (sFc $\gamma$ RIIIb). The subsequent inflammatory response is modulated by several mediators, including neutrophil derived leukotriene $B_{4}\left(\mathrm{LTB}_{4}\right)$, thromboxane $\mathrm{B}_{2}$ $\left(\mathrm{TXB}_{2}\right)$, and prostaglandin $\mathrm{E}_{2}\left(\mathrm{PGE}_{2}\right)$. The aim of this study was to determine the value of gut lavage sFcyRIII and eicosanoid measurements for the assessment of mucosal inflammation in IBD.

Methods-A total of 18 patients with active IBD, 10 ulcerative colitis (UC), and eight Crohn's disease (CD), and 12 control patients underwent whole gut lavage. Disease activity, endoscopic appearance, and histopathology were graded. Samples were processed for the determination of sFc $\gamma$ RIIIb, $\mathrm{LTB}_{4}, \mathrm{PGE}_{2}$, and $\mathrm{TXB}_{2}$.

Results-Soluble Fc $\gamma$ RIIIb concentrations were increased in both IBD groups. Significant correlations were seen between sFc $\gamma$ RIIIb and LTB $_{4}$ values with histology scores. Mean eicosanoid lavage fluid concentrations in control patients were $14 \cdot 1$ $\mathrm{pg} / \mathrm{ml}$ for $\mathrm{LTB}_{4}, 5.6 \mathrm{pg} / \mathrm{ml}$ for $\mathrm{PGE}_{2}$, and $397 \mathrm{pg} / \mathrm{ml}$ for $\mathrm{TXB}_{2}$. Concentrations of all eicosanoids in IBD patients were significantly increased: $\mathrm{LTB}_{4}$ in UC: mean $\mathbf{7 3 . 2}$ $\mathrm{pg} / \mathrm{ml}$, in CD: $96.4 \mathrm{pg} / \mathrm{ml}$ (both $\mathrm{p}<0.01$ $v$ controls). $\mathrm{PGE}_{2}$ in UC: $20.2 \mathrm{pg} / \mathrm{ml}$, in CD: $43.4 \mathrm{pg} / \mathrm{ml}(\mathrm{p}<0.01)$. $\mathrm{TXB}_{2}$ in UC: 719.3 $\mathrm{pg} / \mathrm{ml}$, in CD: $180.6 \mathrm{pg} / \mathrm{ml}$ (both $\mathrm{p}<0.05$ ). Conclusions-Whole gut lavage fluid analysis is an effective method to study mucosal eicosanoid production. Soluble Fc $\gamma$ RIIIb concentrations in gut lavage fluid closely correlate with histological signs of mucosal inflammation and with lavage $\mathrm{LTB}_{4}$ concentration. These data suggest that lavage Fc $\gamma$ RIIIb assessment may be used as a simple assay to estimate mucosal neutrophil infiltration in IBD.

(Gut 1996; 38: 564-567)
\end{abstract}

Keywords: inflammatory bowel disease, Fc $\gamma$ receptor III, eicosanoids, gut lavage fluid.

Neutrophil infiltration of the intestinal mucosa is a feature of active inflammatory bowel disease (IBD). ${ }^{1}$ A significant mediator of neutrophil mucosal recruitment is leukotriene $B_{4}$ $\left(\mathrm{LTB}_{4}\right)$, a product of activated neutrophils. ${ }^{2-4}$ Amelioration of IBD related mucosal inflammation is associated with declining concentrations of all eicosanoids including $\mathrm{LTB}_{4}$, prostaglandin $\mathrm{E}_{2}\left(\mathrm{PGE}_{2}\right.$ : down regulation of mucosal inflammation), and thromboxane $\mathrm{B}_{2}$ $\left(\mathrm{TXB}_{2}\right.$ : vasoconstrictor). ${ }^{5-8}$ Clinically, the effects of eicosanoids are manifested as the occurrence of diarrhoea and abdominal cramps resulting from their effect on smooth muscle contraction, ${ }^{9}$ and epithelial secretion. ${ }^{10}$

Fc gamma receptor III (Fc $\gamma$ RIII) is a low affinity neutrophil surface membrane IgG receptor. FcyRIIIb, expressed exclusively on neutrophils and contributes to the inflammatory response by binding and internalising antibody coated micro-organisms or immune complexes. ${ }^{11-15}$ Soluble forms of FcyRIIIb (sFcyRIIIb) are released upon neutrophil activation, and the $s F c \gamma R I I I b$ concentration has been shown to increase at inflammatory sites. ${ }^{16}$ Consequently, luminal release of this molecule may reflect local neutrophil infiltration.

Whole gut lavage has been used to study humoral immunity in IBD ${ }^{17} 18$ and the assessment of albumin, IgG, and $\alpha_{1}$ antitrypsin in lavage fluid has been proposed as a new approach to measuring disease activity in IBD. ${ }^{1920}$ The aim of this study was to assess gut lavage concentrations of both $s F c \gamma$ RIIIb and eicosanoids, and their correlations with disease activity, to evaluate their usefulness as markers for mucosal inflammation in patients with active IBD.

\section{Methods}

\section{Patients}

Eighteen patients with a previous diagnosis of IBD (ulcerative colitis, UC: Crohn's disease, CD) based on histological, radiological, and endoscopic findings (10 UC and eight CD) underwent whole gut lavage for clinically indicated endoscopy. In three $C D$ patients, the terminal ileum was involved, the remaining CD patients suffered from large bowel disease. Control patients (12) underwent colonoscopy for the investigation of abdominal pain of unknown origin or polyps. The caecum was reached in all cases. 
Endoscopic appearance was scored in UC patients using a previously described scoring scale, ${ }^{21}$ in which an increasing score (0 to 18$)$ pointed to greater macroscopic inflammation. Four biopsy specimens for histopathology were obtained from macroscopically inflamed areas, and scored in a blinded fashion, using a predefined scoring scale with 14 relevant parameters, ${ }^{22}$ with a maximal score of 22 points. Disease activity was assessed using the PowellTuck index (PTI) ${ }^{23}$ for UC patients, and the Crohn's Disease Activity Index (CDAI ${ }^{24}$ for CD patients. This study was approved by the medical ethical committee of the Academic Medical Centre in Amsterdam.

\section{Gut lavage procedure}

An isotonic non-absorbable lavage fluid (sodium $125 \mathrm{mmol} / \mathrm{l}$, potassium $10 \mathrm{mmol} / \mathrm{l}$, sulphate $40 \mathrm{mmol} / 1$, chloride $35 \mathrm{mmol} / 1$, bicarbonate $20 \mathrm{mmol} / \mathrm{l}$ ) was given through a gastric tube at a rate of $1-1.5$ litre per hour. When clear fluid passed the rectum (usually within two hours), free of faecal debris, $20 \mathrm{ml}$ was collected from each patient. Within 10 minutes the lavage fluid was processed as described previously. ${ }^{18-20}$ In brief, fluid was filtered through a GF/A glass fibre filter (Whatman Scientific, Kent, England) and to the filtrate, soybean trypsin inhibitor, sodium EDTA, phenyl methyl sulphonyl fluoride, sodium azide, and fetal calf serum was added. Samples were then stored at $-70^{\circ} \mathrm{C}$ until assay.

\section{Eicosanoid and sFc $\gamma R I I I$ measurements}

Samples for eicosanoid estimation were extracted through Amprep $\mathrm{C}_{2}\left(\mathrm{LTB}_{4}\right.$ and $\mathrm{TXB}_{2}$ ) and $\mathrm{C}_{18}\left(\mathrm{PGE}_{2}\right)$ columns (Amersham, England). $\mathrm{LTB}_{4}, \mathrm{PGE}_{2}$, and $\mathrm{TXB}_{2}$ were measured using commercial Biotrak enzyme linked immunosorbent assays (ELISAs) (Amersham). The lower detection limits of these ELISAs were $0.31 \mathrm{pg}, 1 \mathrm{pg}$, and $0.5 \mathrm{pg}$ respectively. The extraction procedure and assays were validated by the use of samples of lavage fluid containing added known quantities of each eicosanoid. Recovery for all eicosanoids was $>90 \%$. There was no detectable cross reactivity between $\mathrm{LTB}_{4}$, $\mathrm{PGE}_{2}$, nor $\mathrm{TXB}_{2}$.

Soluble FcyRIII was determined by a radioimmunoassay as previously described. ${ }^{25}$ The capture antibody for this assay was CLBFcRgran 1 (Central Laboratory of the Red Cross (CLB), Amsterdam), detection being with a ${ }^{125}$ I labelled pan-FcyRIII antibody (BW209/2, a gift of Dr R Kurrle, Behringwerke AG, Marburg). The intra-assay coefficient of variation for this assay was $<5 \%$. This assay does not distinguish between FcyRIIIa or FcyRIIIb gene expression, and therefore does not specify its cellular origin. The FcyRIIIb gene encodes for the codominant biallelic NA1NA2 system. To establish the cellular origin of sFc $\gamma$ RIII in lavage fluid, we determined the Fc $\gamma$ RIIIb NA1/NA2 allotypes in plasma of eight study patients using an NA1-RIA. ${ }^{1725}$ Using donor serum samples known to be FcyRIIIb-NA1/NA1 positive, the binding of CLB GRAN11 (anti-Fc $\gamma$ RIIIbNA1) relative to BW209/2 (anti-pan-Fc $\gamma$ RIII) was determined and set as $100 \%$ relative binding. The NA phenotype of soluble Fc $\gamma$ RIIIb in patients was assigned as Fc $\gamma$ RIIIb-NA1/NA1 ( $>80 \%$ relative binding of CLB GRAN11), FcyRIIIb-NA1/NA2 (10-80\%), or Fc $\gamma$ RIIIbNA2/NA2 $(<10 \%)$. sFcyRIII values are expressed in arbitrary units.

\section{Statistical analysis}

Statistics were calculated using the SPSS 6.0 for Windows (SPSS Inc, USA). Values are given as means (SEM). Differences between groups were analysed using the Mann-Whitney test, and analysis of variance where appropriate. Correlations were calculated using Spearman correlation coefficients. Alpha was set at $0 \cdot 05$.

\section{Results}

\section{Patients}

In UC patients, disease activity (PTI) ranged from 2-11 points (mean 5.4 (1.0)), in CD patients disease activity (CDAI) ranged from 21-390 points (mean $174 \cdot 5(40)$ ). The distribution of treatment regimens were similar in both disease groups with respect to the use of sulphasalazine/5-ASA, corticosteroids, and immunosuppressive drugs. The lavage procedure was well tolerated in all patients and all samples were processed immediately after colonoscopy. In UC patients, the endoscopic scores varied between 2 and 14 points (mean 5.7 (1.1)) and the histopathology scores in this group ranged from 5 to 15 $(8.9(0.9))$. The mean histopathology score in CD patients was $11.4(1 \cdot 3)$ points (range 6-17).

\section{$s F c \gamma R I I I$}

The Figure (A) shows the sFc $\gamma$ RIII concentrations. In control patients the $s F c \gamma R I I I$ concentration ranged from 1.0 to 6.0 units (mean 3.2 $(0 \cdot 5))$. In both study groups, sFcyRIII values were increased: in UC patients a mean value was seen of 35 (20) units ( $\mathrm{p}=0.05 v$ control), in CD patients the mean value was 113 (47) units $(\mathrm{p}=0.05 v$ control).

To determine the cellular origin of sFcyRIII, the NA-polymorphism was determined in the serum samples of eight patients with active CD: five patients were found to be homozygous NA2NA2, one patient homozygous NA1NA1, and two patients were heterozygous NA1NA2. In the lavage fluid of the three NA1 positive patients, NA1-sFc $\gamma$ RIII was detected in considerable amounts (mean 233 arbitrary units). In all NA2NA2 patients, lavage fluid concentrations of NA1-sFc $\gamma$ RIII were negative. Hence, the NA-polymorphism that was predicted from serum was also found in lavage fluid. This finding suggests that the $\mathrm{sFc} \gamma \mathrm{RIII}$ detected in lavage fluid originated from neutrophils. 

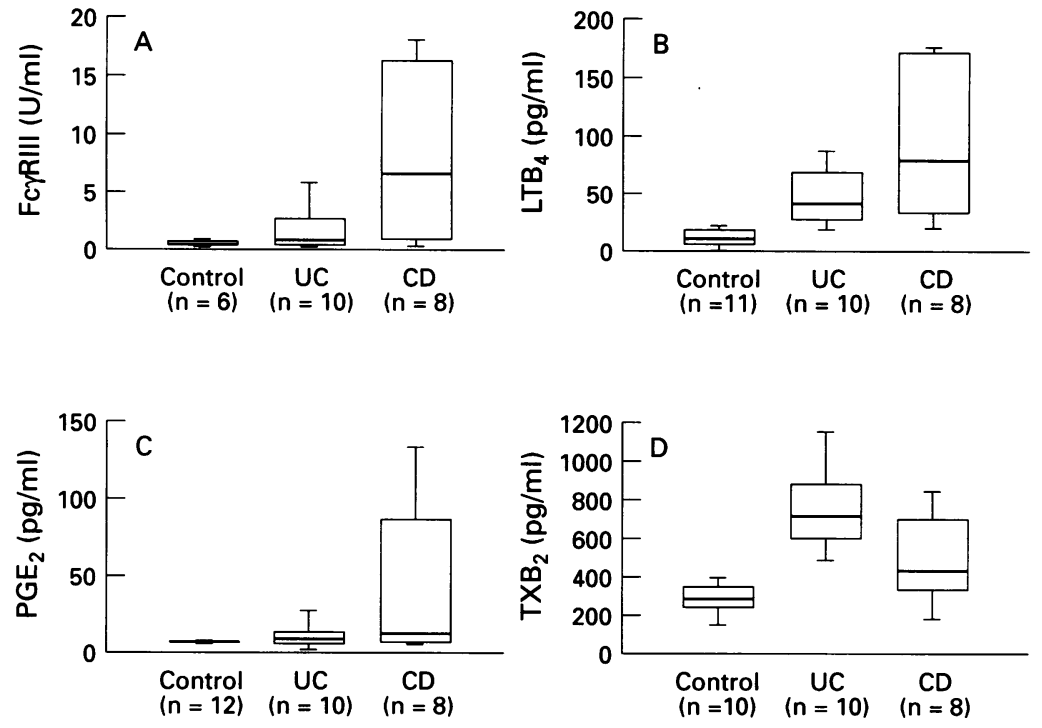

Box plots of lavage fluid concentrations: soluble Fc $\gamma R$ III receptor (arbitrary units) $(A)$; leukotriene $B_{4}(\mathrm{pg} / \mathrm{ml})(B)$; prostaglandin $E_{2}(\mathrm{pg} / \mathrm{ml})(C)$, and thromboxane $B_{2}(\mathrm{pg} / \mathrm{ml})$ (D) in patients with UC and CD versus controls. Boxes and heavy lines represent $25-75 \%$ interquartile range and median respectively. Light lines represent range of results.

\section{Eicosanoids}

The mean $\mathrm{LTB}_{4}$ value measured $14 \cdot 2(3 \cdot 1)$ $\mathrm{pg} / \mathrm{ml}$ in controls, whereas this was $73 \cdot 2(29 \cdot 3)$ $\mathrm{pg} / \mathrm{ml}$ in UC patients $(\mathrm{p}<0.01 v$ control) and $96.4(22.7) \mathrm{pg} / \mathrm{ml}$ in CD patients $(\mathrm{p}<0.01 v$ control) (Fig (B). Figure (C) shows $\mathrm{PGE}_{2}$ values. In UC patients, a mean of $20.2(10.5)$ $\mathrm{pg} / \mathrm{ml}$ versus $5.6(0.23) \mathrm{pg} / \mathrm{ml}$ in control patients was measured. In CD patients these values increased even further (mean of 43.4 $(17 \cdot 9) \mathrm{pg} / \mathrm{ml}$ ). The difference between $\mathrm{CD}$ patients and controls was significant $(p<0.01)$. Lavage $\mathrm{TXB}_{2}$ concentrations in control patients ranged from 155.4 to $397 \mathrm{pg} / \mathrm{ml}$ (mean 287.3 (22.2) pg/ml) (Fig 1D), in UC patients these concentrations were significantly higher (mean $719.3(76.7) \mathrm{pg} / \mathrm{ml}, \mathrm{p}<0.01)$. In CD patients the mean $\mathrm{TXB}_{2}$ value was 549.7 $(120 \cdot 8) \mathrm{pg} / \mathrm{ml}$, which also differed significantly from controls $(p<0 \cdot 05)$.

\section{Correlations}

In UC patients, $\mathrm{sFc} \gamma \mathrm{RIII}$ correlated well with the endoscopic score $(r=0.77, \mathrm{p}<0.01)$, weaker correlations were found between sFc $\gamma$ RIII and histology scores $(r=0.60$, $\mathrm{p}=0.08)$ and disease activity $(r=0.61$, $\mathrm{p}=0 \cdot 06) . \mathrm{LTB}_{4}$ concentrations correlated with the histology score in UC patients $(r=0.63$, $\mathrm{p}<0.05$ ).

In CD patients, $\mathrm{sFc} \gamma \mathrm{RIII}$ values correlated strongly with histology scores $(r=0.92$, $\mathrm{p}<0.01), \mathrm{LTB}_{4}(r=0.9, \mathrm{p}<0.01)$, and $\mathrm{TXB}_{2}$ $(r=0.72, \mathrm{p}<0.05)$. Moreover, $\mathrm{LTB}_{4}$ values correlated strongly with histology scores in $\mathrm{CD}$ patients $(r=0 \cdot 89, \mathrm{p}<0 \cdot 01)$.

\section{Discussion}

The results of this study show that the $\mathrm{sFc} \gamma \mathrm{RIII}$ concentration in gut lavage fluid obtained from patients with IBDs reflects the mucosal inflammatory reaction. Both in CD and UC, the lavage sFc $\gamma$ RIII concentration correlated well with the histologically determined degree of mucosal inflammation.

FcyRIII is the low affinity receptor of IgG, which is expressed by neutrophils, natural killer $T$ cells, and macrophages. ${ }^{11-14}$ Two forms of FcyRIII have been characterised: a transmembrane protein (FcyRIIIa) that is expressed by macrophages and natural killer cells, and FcyRIIIb that is expressed exclusively by neutrophils. Fc $\gamma$ RIII binds dimers, trimers, immune complexes, and opsonisised particles, thereby activating neutrophils. Upon activation, proteolytic cleavage of FcyRIII from the membrane takes place, and soluble forms of Fc $\gamma$ RIII are released. ${ }^{26} 27$

The assay used to determine the lavage $s F c \gamma R I I I$ concentration in this study does not distinguish between FcyRIIIa or FcyRIIIb gene expression. Although it has been reported that most, if not all plasma sFc $\gamma$ RIII is derived from neutrophils, ${ }^{27}$ we attempted to establish the cellular origin of $\mathrm{sFc} \gamma \mathrm{RIII}$ in lavage fluid. Firstly, by using the anti-NA1-Fc $\gamma$ RIIIb-antibody (CLB GRAN11), the NA allotypes in all $\mathrm{CD}$ patients were determined. Because most plasma FcyRIII is derived from neutrophils, and the FcyRIIIb-gene encodes exclusively for Fc $\gamma$ RIII on neutrophils, ${ }^{1528}$ the sFcyRIIIbNA1/Fc $\gamma$ RIII ratio in plasma permits prediction of the NA1/NA2 phenotype. Of the eight tested CD patients, five were typed to be NA2/NA2 homozygous, one NA1/NA1 homozygous, and two NA1/NA2 heterozygous. NA1-sFc $\gamma$ RIIIb analysis in lavage fluids showed a significant amount in all NA1 positive patients, and no NA1-sFc $\gamma$ RIIIb in NA2NA2 positive patients. Hence the NA polymorphism that was predicted from plasma was also found in lavage fluid. This finding strongly suggests that the FcyRIII in lavage fluid originated from neutrophils.

A significant correlation was seen between $s F c \gamma$ RIII and $\mathrm{LTB}_{4}$ lavage concentrations, a leukotriene with well recognised neutrophil chemoattracting and activating action. $\mathrm{sFc} \gamma \mathrm{RIII}$ values correlated well with the histology scores (UC: $r=0 \cdot 60, \mathrm{CD}: r=0 \cdot 89$ ). $\mathrm{LTB}_{4}$ concentrations correlated with histology scores (UC: $r=0.63, \mathrm{CD}: r=0.89$ ). These findings show that $\mathrm{sFc} \gamma \mathrm{RIII}$ and $\mathrm{LTB}_{4}$ in lavage fluid in IBD patients reflect the mucosal neutrophil induced inflammation. The score derived from the endoscopic scoring system used reflects the greatest degree of inflammation seen rather than assesses the geographical extent of this process. Consequently, comparatively small areas of mucosal inflammation may have a significant influence on the concentrations of luminal inflammatory mediators detected.

The concentrations of both the pro-inflammatory $\mathrm{LTB}_{4}$ and $\mathrm{TXB}_{2}$ as well as the cytoprotective $\mathrm{PGE}_{2}$ were significantly increased in $\mathrm{CD}$ and UC. These results are comparable to previous studies that have found increased concentrations of $\mathrm{LTB}_{4}$ and $\mathrm{PGE}_{2}$ in rectal dialysis of UC patients, ${ }^{29}$ and in the mucus of ulcerative proctocolitis. ${ }^{30}$ Measurement of eicosanoids in lavage fluid does not require insertion of a rectal dialysis bag, and therefore is more feasible. In addition, lavage fluid 
eicosanoid concentration may better reflect the amount of eicosanoids produced by the total area of inflamed bowel, especially in CD, which may be patchy. Hence this method could be used to monitor mucosal inflammation in clinical intervention studies in IBD. Our results emphasise the difficulties of attempting to correlate mucosal inflammatory mediator production with clinical parameters of IBD activity.

In conclusion, we have shown that the sFc $\gamma \mathrm{RIII}$ and $\mathrm{LTB}_{4}$ lavage fluid concentration reflects mucosal inflammation. Because the sFcyRIII in lavage fluid was shown to originate from neutrophils, and neutrophils are known to be the major source of $\mathrm{LTB}_{4}$ within the bowel mucosa, these measurements probably reflect mucosal neutrophil infiltration.

1 Weiss SJ. Tissue destruction by neutrophils. $N$ Engl $f$ Med 1989; 320: 365-76.

2 Ford-Hutchinson AW. Leukotriene $B_{4}$ in inflammation. Crit Rev Immunol 1990; 10: 1-12.

3 Sharon P, Stenson WF. Enhanced synthesis of leukotriene $\mathrm{B}_{4}$ by colonic mucosa in inflammatory bowel disease. Gastroenterology 1984; 86: 453-60.

4 Lauritsen K, Laursen LS, Bukhave K, Rask-Madsen J. In vivo profiles of eicosanoids in ulcerative colitis, Crohn's colitis and Clostridium difficile colitis. Gastroenterology 1988; 95: 11-7.

5 Lauritsen K, Laursen LS, Bukhave K, Rask-Madsen J. Effects of topical 5-aminosalicylic acid and prednisolone on prostaglandin $\mathrm{E}_{2}$ and leukotriene $\mathrm{B}_{4}$ levels determined by equilibrium in vivo dialysis of rectum in relapsing ulcerative colitis. Gastroenterology 1986; 91: 837-44.

6 Phipps RP, Stein SH, Roper RL. A new view of prostaglandin $\mathrm{E}$ regulation of the immune response. prostaglandin $\mathrm{E}$ regulation of the

7 Hawkey CJ, Karmeli F, Rachmilewitz D. Imbalance of prostacyclin and thromboxane synthesis in Crohn's disease. Gut 1983; 24: 881-5.

8 Whittle BJR, Kauffman GL, Moncada S. Vasoconstriction with thromboxane $A_{2}$ induces ulceration of the gastric mucosa. Nature 1981; 292: 472-4.

9 Percy WH, Burton MB, Fallick F, Burakoff R. A comparison in vitro of human and rabbit distal colonic muscle responses to inflammatory mediators. Gastroenterology 1990; 99: 1324-32.

10 Donowitz $M$. Arachidonic acid metabolites and their role in inflammatory bowel disease. Gastroenterology 1985; 88: $580-7$

11 Fleit HB, Wright SD, Unkeless JC. Human neutrophil Fcy receptor distribution and structure. Proc Natl Acad Sci USA 1982; 79: 3275-9.

12 Perussia B, Trinchieri G. Antibody 3G8, specific for the human neutrophil $\mathrm{Fc}$ receptor, reacts with natural killer cells. F Immunol 1984; 132: 1410-5.

13 Clarkson SB, Kimberly RB, Valinsky JE, Witmer MD Bussell JB, Nachman RI Unkeless JC. Blockade of clearance of immune complexes by anti-FcR monoclonal antibody. F Exp Med 1986; 164: 474-89.

14 Clarkson SB, Ory PA. CD16: developmentally regulated IgG Fc receptors on cultured human monocytes. $f$ Exp Med 1988; 167: 408-20.

15 Huizinga TW, Kleijer M, Tetteroo PA, Roos D, von dem Borne AEGKr. Biallelic neutrophil NA-antigen system is associated with a polymorphism on the phospho-inositollinked Fc gamma receptor III (CD16). Blood 1990; 75: linked Fc

16 Fleit HB, Kobasiuk CB, Doly C, Furie R, Levy PC, Webster RO. A soluble form of FcyRIII is present in human serum and other body fluids and is elevated at sites of inflammation. Blood 1992; 79: 2721-8.

17 O'Mahony S, Barton JR, Crichton S, Ferguson A. Appraisal of gut lavage in the study of intestinal humoral immunity. Gut 1990; 31: 1341-4.

18 O'Mahony S, Choudari CP, Barton JR, Walker S, Ferguson A. Gut lavage fluid proteins as markers of activity of A. Gut lavage fluid proteins as markers of activity of 26: $940-4$.

19 Choudari CP, O'Mahony S, Brydon G, Mwantembe O, Ferguson A. Gut lavage protein concentrations: objective measures of disease activity in inflammatory bowel disease. Gastroenterology 1993; 104: 1064-71.

20 Brydon WG, Choudari CP, Ferguson A. Relative specificity for active inflammatory bowel disease of plasma-derived proteins in gut lavage fluid. Eur $\mathcal{f}$ Gastroenterol Hepatol 1993; 5: 269-73.

21 Mulder CJJ, Tytgat GNJ, Wiltink EHH, Houthoff HJ. Comparison of 5-aminosalicylic acid $(3 \mathrm{~g})$ and prednisolone phote nisolone phosphate sodium enemas (30 $\mathrm{mg}$ ) in the treatment of distal ulcerative colitis: a prospective, randomized

22 Seldenrijk CA, Morson BC, Meuwissen SGM, Schipper NW, Lindeman J, Meijer CJLM. Histopathological evaluation of colonic mucosal biopsy specimens in chronic inflammatory bowel disease; diagnostic implications. Gut 1991; 32: 1514-20.

23 Powell-Tuck J, Bown RL, Lennard-Jones JE. A comparison of oral prednisolone given as a single or multiple daily doses for active proctocolitis. Scand 7 Gastroenterol 1978 ; 13: 833-7.

24 Best WR, Becktel JM, Singleton JW, Kern F. Development of a Crohn's disease activity index: National Cooperative Crohn's Disease Study. Gastroenterology 1976; 70: 439-44.

25 Huizinga TWJ, de Haas M, van Oers MHJ, Kleijer M, Vile $\mathrm{H}$, van der Wouw PA, et al. The plasma concentration of soluble Fc-gamma RIII is related to production of neutrophils. Br f Haematol 1994; 87: 459-63.

26 Huizinga TWJ, van der Schoot CE, Jost C, Klaassen $R$, Kleijer M, von dem Borne AEG, et al. The PI-linked receptor FCRIII is released on stimulation of neutrophils. Nature 1988; 333: 667.

27 Huizinga TW, de Haas M, Kleijer M, Nuijens JH, Roos D, von dem Borne AEGKr. Soluble Fc gamma receptor III in human plasma originates from release by neutrophils. $f$ human plasma originates from

28 De Haas $M$, Kleijer M, Minchinton RM, Roos D, von dem Borne AEGKr. Soluble FcrRIIIa is present in plasma and is derived from natural killer cells. $\mathscr{f}$ Immunol 1994; 152: 900-7.

29 Laursen LS, Naesdal J, Bukhave K, Lauritsen K, RaskMadsen J. Selective 5-lipoxygenase inhibition in ulcerative colitis. Lancet 1990; 335: 683-5.

30 Zijlstra FJ, Wilson JH. 15-HETE is the main eicosanoid present in mucus of ulcerative proctocolitis. Prostaglandins Leukot Essent Fatty Acids 1991; 43: 55-9. 